\title{
Recent Developments in Therapeutic and Nutraceutical Applications of $p$-Methoxycinnamic Acid from Plant Origin
}

\author{
Anna Płowuszyńska and Anna Gliszczyńska *(D) \\ Department of Chemistry, Wrocław University of Environmental and Life Sciences, Norwida 25, \\ 50-375 Wrocław, Poland; annaplowuszynska@gmail.com \\ * Correspondence: anna.gliszczynska@wp.pl; Tel.: +48-71-320-5183
}

Citation: Płowuszyńska, A.; Gliszczyńska, A. Recent

Developments in Therapeutic and Nutraceutical Applications of p-Methoxycinnamic Acid from Plant Origin. Molecules 2021, 26, 3827. https://doi.org/10.3390/ molecules 26133827

Academic Editor: Matej Sova

Received: 9 June 2021

Accepted: 21 June 2021

Published: 23 June 2021

Publisher's Note: MDPI stays neutral with regard to jurisdictional claims in published maps and institutional affiliations.

Copyright: (c) 2021 by the authors. Licensee MDPI, Basel, Switzerland. This article is an open access article distributed under the terms and conditions of the Creative Commons Attribution (CC BY) license (https:// creativecommons.org/licenses/by/ $4.0 /)$.

\begin{abstract}
The $p$-methoxycinnamic acid ( $p$-MCA) is one of the most studied phenylpropanoids with high importance not only in the wide spectrum of therapeutic activities but also its potential application for the food industry. This natural compound derived from plants exhibits a wide range of biologically useful properties; therefore, during the last two decades it has been extensively tested for therapeutic and nutraceutical applications. This article presents the natural sources of $p$-MCA, its metabolism, pharmacokinetic properties, and safety of its application. The possibilities of using this dietary bioactive compound as a nutraceutical agent that may be used as functional food ingredient playing a vital role in the prevention and treatment of many chronic diseases is also discussed. We present the antidiabetic, anticancer, antimicrobial, hepato-, and neuroprotective activities of $p$-MCA and methods of its lipophilization that have been developed so far to increase its industrial application and bioavailability in the biological systems.
\end{abstract}

Keywords: $p$-methoxycinnamic acid; polyphenols; phenylpropanoids; methoxylated derivatives of cinnamic acid; biological activity

\section{Introduction}

Phenolic acids, due to their broad occurrence in nature and wide spectrum of therapeutic activity, have become the subject of many scientific studies [1]. Among this group of secondary metabolites of plants, $p$-methoxycinnamic acid ( $p$-MCA, 4-methoxycinnamic acid, 4MCA) is of particular interest and is one of the most studied methoxy derivatives of cinnamic acid (CA). It is a compound that is commonly found in the plant world and delivered to the body through food products, mainly coffee (Coffea arabica) [2], peanuts (Arachis hypogaea) [3], cereal plants such as buckwheat (Fagopyrum esculentum) [4], and bicolor sorghum (Sorghum vulgare) [5]. Rich sources of $p$-MCA also include cereal products such as brown rice grains (Oryza sativa L.) [6] and rice bran [7]. This monomethoxy derivative of cinnamic acid has been detected in the leaves of pineapples [8] and roots of a species of banana, Musa acuminate [9]. It is also the compound that determines the strong antimicrobial effect of the methanol extract obtained from the seeds of yuzu (Citrus junos) fruit against the strains of Escherichia coli and Salmonella enteritidis bacteria responsible for the majority of gastrointestinal infections in humans [10]. In addition, $p$-MCA is a biologically active ingredient of many other various spices of plants. Its presence has been confirmed in the Curcuma longa, kencur galangal (Kaempferia galanga) [7] and in the rhizomes of a less known but equally valued plant in southeastern medicine, Etlingera pavieana [11]. This compound has been reported as an important component of the herbs of chamomile (Matricaria chamomilla) [12], Anigozanthos preissii [13], Dianthus superbus L. [14], and Prostanthera rotundifolia [15] and a constituent of products used in industry like Hibiscus cannabinus [16] or Chinese agarwood [17]. Particularly interesting sources of $p$-MCA are endemic plants found in countries of southern Africa, especially Wachendorfia thyrsiflora and Anigozanthos preissii [13]. So far, p-MCA has also been isolated from many wild plants. The 
most common, naturally occurring sources of this acid include plants from the Asteraceae, Scrophulariaceae, and Rutaceae families. Natural sources of $p$-MCA are presented in Table 1.

Table 1. Natural sources of $p$-methoxycinnamic acid.

\begin{tabular}{|c|c|c|c|}
\hline Natural Source & Plant Families & Content & Ref. \\
\hline Avicennia marina leaves & Acanthaceae & - & [18] \\
\hline Maples (Acer spp.) & Aceraceae & - & [19] \\
\hline Notopterygium incisum roots & Apiaceae & - & [20] \\
\hline $\begin{array}{c}\text { Carnauba wax, carnauba tree leaves } \\
\text { (Copernicia Cerifera) }\end{array}$ & Arecaceae & $0.3 \mathrm{~g} / 100 \mathrm{~g}$ of wax powder & {$[21]$} \\
\hline Chamomile (Matricaria chamomilla L.) & \multirow{3}{*}{ Asteraceae } & - & {$[12]$} \\
\hline $\begin{array}{l}\text { Chrysanthemum zawadskii roots } \\
\text { (Dendranthema zawadskii var. latilobum) }\end{array}$ & & $36 \mathrm{mg} / 1.65 \mathrm{~kg}$ of fresh roots & [22] \\
\hline Aerial parts of Atractylodes macrocephala & & $40 \mathrm{mg} / 15 \mathrm{~kg}$ & [23] \\
\hline Balanophoru tobiracola Makino & Balanophoraceae & $\begin{array}{l}60 \mathrm{mg} / 8 \mathrm{~kg} \text { of fresh whole plant } \\
\text { (100 g MeOH extract) }\end{array}$ & [24] \\
\hline Pineapple leaves (Ananas comosus) & Bromeliaceae & - & [8] \\
\hline Dianthus superbus L. & Caryophyllaceae & - & [14] \\
\hline Mallotus conspurcatus & Euphorbiaceae & - & [25] \\
\hline $\begin{array}{l}\text { Peanut hypocotyl and roots Arachis hypogaea } \\
\text { (most in Georgia Green) }\end{array}$ & Fabaceae & $\begin{array}{c}1.6 \pm 0.7 \mu \mathrm{g} / \mathrm{g} \text { of wet Georgia } \\
\text { Green hypocotyl } \\
17.5 \pm 3.7 \mu \mathrm{g} / \mathrm{g} \text { of wet Georgia Green root }\end{array}$ & [3] \\
\hline Anigozanthos preissii roots & \multirow{2}{*}{ Haemodoraceae } & - & {$[13]$} \\
\hline Wachendorfia thyrsiflora roots & & - & [13] \\
\hline Prostanthera rotundifolia leaves & Lamiaceae & $\begin{array}{c}94.7 \pm 1.0 \mathrm{mg} \text { gallic acid equivalent/g DW } \\
\text { purified extract }\end{array}$ & [15] \\
\hline Plicosepalus curviflorus leaves & Loranthaceae & $350 \mathrm{mg} / 1 \mathrm{~kg}$ of leaves & [26] \\
\hline Kenaf (Hibiscus cannabinus) & Malvaceae & - & [16] \\
\hline Moringa oleifera leaves & Moringaceae & - & [27] \\
\hline Musa acuminata roots & Musaceae & - & [9] \\
\hline Piper philippinum stems & Piperaceae & $0.9-2.1 \mathrm{mg} / 4 \mathrm{~kg}$ of dried stems & [28] \\
\hline Rice bran (Oryza sativa L.) & \multirow{5}{*}{ Poaceae } & - & [7] \\
\hline Phyllostachys bambusoides culms & & $5.8 \mathrm{mg} / 5 \mathrm{~kg}$ of dried bamboo powder & [29] \\
\hline Sugarcane juice (Saccharum officinarum) & & - & {$[30]$} \\
\hline Brown rice (Oryza sativa L.) & & - & [6] \\
\hline Sorghum root (Sorghum vulgare) & & - & {$[5]$} \\
\hline Polygalae tenuifolia roots & Polygalaceae & $64 \mathrm{mg} / 8 \mathrm{~kg}$ of whole dried plant & {$[31]$} \\
\hline $\begin{array}{l}\text { Buckwheat inflorescences (most in } \\
\text { Fagopyrum esculentum) }\end{array}$ & Polygonaceae & $\begin{array}{c}14.1 \pm 7.9 \mathrm{mg} / 100 \mathrm{~g} \mathrm{DW} \text { of } F . \text { tataricum } \\
74.7 \pm 24.0 \mathrm{mg} / 100 \mathrm{~g} \text { DW of } F . \text { esculentum } \\
17.7 \pm 3.3 \mathrm{mg} / 100 \mathrm{~g} \text { DW of } F . \text { esculentum } \\
\text { green flowers }\end{array}$ & [4] \\
\hline European Columbine leaves (Aquilegia vularis) & Ranunculaceae & - & {$[32]$} \\
\hline Aerial parts of Sibiraea angustata & Rosaceae & - & [33] \\
\hline Green Arabic coffee beans (Coffea arabica) & Rubiaceae & - & {$[2]$} \\
\hline
\end{tabular}


Table 1. Cont.

\begin{tabular}{|c|c|c|c|}
\hline Natural Source & Plant Families & Content & Ref. \\
\hline Hyptis salzmannii leaves & & $0.3 \mathrm{~g} / 1.1 \mathrm{~kg}$ of dried leaves powder & [34] \\
\hline Murraya euchrestifolia fruits & & $60 \mathrm{mg} / 650 \mathrm{~g}$ extract of fruit & [35] \\
\hline Yuzu seed (Citrus junos) & Rutaceae & 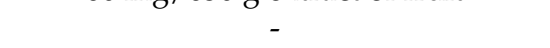 & {$[10]$} \\
\hline Toddalia root (Toddalia asiatica) & & - & [36] \\
\hline Scrophularia buergeriana, S. ningpoensis roots & & $0.212 \mathrm{~g} / 4 \mathrm{~kg}$ dried powder roots & [37] \\
\hline Aerial parts of Buddleja asiatica & Scrophulariaceae & $30 \mathrm{mg} / 12.5 \mathrm{~kg}$ of air-dried aerial parts & {$[38]$} \\
\hline Scrophularia Ningpoensis roots & & $8.8 \mathrm{mg} / 25 \mathrm{~kg}$ of dried roots & [39] \\
\hline Ailanthus integrifolia bark & Simaroubaceae & $7.6 \mathrm{mg} / 3 \mathrm{~kg}$ of dried bark & [40] \\
\hline Chinese agarwood & Thymelaeaceae & - & [17] \\
\hline Duranta repens leaves & Verbenaceae & $25 \mathrm{mg} / 17 \mathrm{~kg}$ of leaves & [41] \\
\hline Turmeric (Curcuma longa L.) & & - & [7] \\
\hline Kencur (Kaempferia galanga) & Zingiberaceae & - & {$[7]$} \\
\hline Etlingera pavieana rhizomes & & - & {$[11]$} \\
\hline
\end{tabular}

\section{Metabolism of $p$-MCA}

The metabolic pathway of $p$-MCA has been studied by Woo following its intravenous and oral administration on a rabbit model [42]. It was observed that for both ways of application, $p$-MCA underwent rapid metabolism and its elimination from the body was clearly dependent on the tract of its delivery. After oral administration of $p$-MCA at a dose of $100 \mathrm{mg} / \mathrm{kg}$ to fasted rabbits, its maximum serum concentration of $7.38 \mathrm{mg} / 100 \mathrm{~mL}$ was observed within $1 \mathrm{~h}$. Moreover, during this study, a linear relationship between maximum concentration and dose was observed as well as the differences in the kinetics of the reaction of elimination of $p$-MCA form serum. At a small dose $(100 \mathrm{mg} / \mathrm{kg})$, elimination of $p$-MCA was found to proceeded by first-order kinetics, whereas at higher doses (300 and $500 \mathrm{mg} / \mathrm{kg}$ ), elimination did not follow the first-order kinetics until the amount remaining in the serum was decreased to a concentration of $17 \mathrm{mg} / 100 \mathrm{~mL}$. Following intravenous injection, the acid was very rapidly metabolized in serum with a half-life $0.4 \mathrm{~h}$. A maximum serum concentration of $41 \mathrm{mg} / 100 \mathrm{~mL}$ was detected three minutes after injection of a dose of $100 \mathrm{mg} / \mathrm{kg}$. For this way of administration, the elimination of $p$-MCA from the serum followed first-order kinetics (the reaction rate was proportional to the substrate concentration and its value decreased with time) and was preceded by an earlier short phase of apparent lateness.

The research conducted by Konishi and coworkers provided more interesting data on the structural specificity of the monocarboxylic acid transporter (MCT) for the transport of $p$-MCA and other phenolic acids by measuring the inhibitory effect on the fluorescein transport across Caco-2 cell monolayers [43]. The amount of fluorescein transported was measured by incubating Caco- 2 in the presence or absence of selected phenolic acids at a temperature of $39.9^{\circ} \mathrm{C}$ for $40 \mathrm{~min}$. It was observed that all meta-substituted methoxy derivatives of benzoic and cinnamic acids showed twice the inhibitory effect or even higher on fluorescein penetration than corresponding meta-hydroxy derivatives, suggesting that meta-hydroxylation of the substrate would decrease the affinity for MCT. However, this was not observed in the case of ortho- and para-substituted derivatives and the relative permeation value for $p$-methoxycinnamic acid was estimated as $73.2 \pm 7.6 \%$, whereas for $p$-coumaric acid it was $84.1 \pm 2.2 \%$ [43]. The study of the inhibitory effect on fluorescein transport across Caco-2 monolayers was the initial evaluation of the intestinal absorption and availability of dietary $p$-MCA and other derivatives of aromatic acids. Wen and Walle proved that methylated (poly)phenols are characterized by a five- to eightfold higher oral absorption and higher metabolic stability than their hydroxylated forms [44]. Methylation 
removes the influence of the highly efficient conjugation pathways limiting the metabolic clearance in the intestinal epithelial cells as well as in the liver.

It has been evaluated that when $p$-methoxycinnamic acid is administrated to humans and rabbits it is oxidized to $p$-methoxybenzoic acid ( $p$-MBA), and after subsequent conjugation with glycine and glucuronic acid it is excreted via urine [42]. This compound has been found to be one of five metabolites of ethylhexyl methoxycinnamate (EHMC) [45] most frequently used as UV filters in sunscreens and is a substance rapidly cleared (half-life $\leq 48 \mathrm{~min}$ ) from human hepatocytes and quickly metabolized [46].

\section{Therapeutic Activity of $p$-MCA}

Phenolic compounds are of special interest to consumers and food manufacturers due to their wide distribution in the plant kingdom and documented reports on their ability to prevent and reduce the risk of several diseases. The amount of phenolic acid administrated via diet reaches $600-800 \mathrm{mg}$ per day, which is about half of the average dose of all polyphenolic compounds taken every day with food $(\sim 1700 \mathrm{mg})$. Most of this amount $(\sim 500-700 \mathrm{mg})$ are derivatives of cinnamic acid, which can be commonly found in plant foods and beverages $[47,48]$. Over the last years, the interest of many research groups in the cinnamic acid moiety has notably increased. The number of publications focused on research dedicated to cinnamic acid and its derivatives with the word "cinnamic" in the title in the Scopus database increased from 341 in the year 2003 to 2226 currently in 2021. This proves that natural compounds from this group are increasingly gaining the attention of researchers. In the last two decades, one of the most extensively studied phenylpropanoids has been $p$-methoxycinnamic acid. Many studies in the literature present a wide range of biological properties of this biomolecule as well as its medical applications as an anticancer, antidiabetic, antimicrobial, and neuro- and hepatoprotective agent (Figure 1). We summarized in this review the pharmacological data of $p$-MCA, analyzed its therapeutic outcomes, and reviewed the methods of its lipophilization, which were studied for the increase of its bioavailability in the human body and effectiveness of action so far.

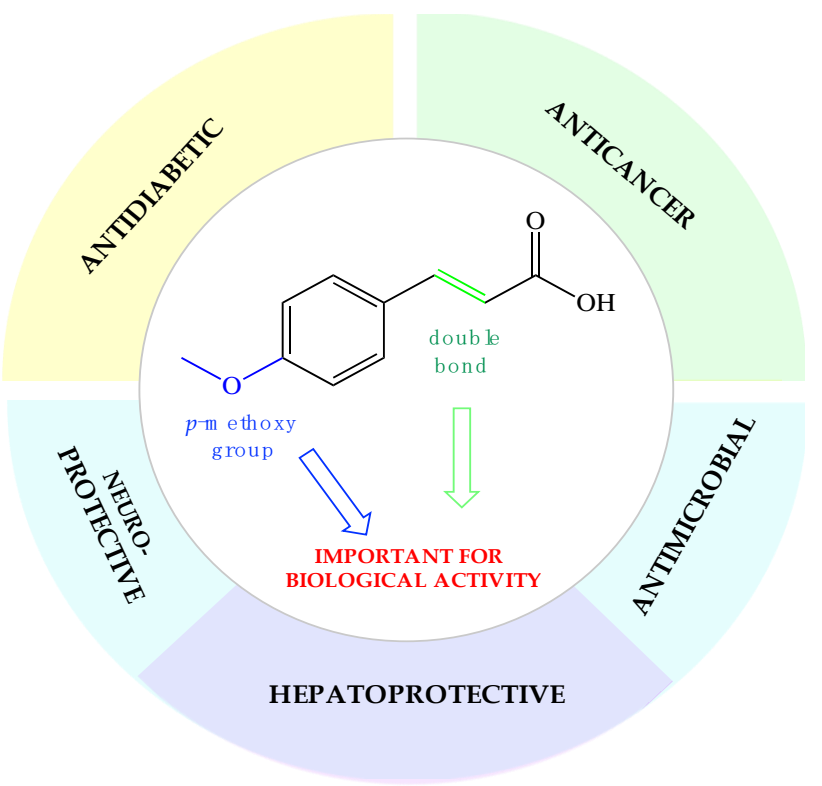

Figure 1. Biological applications of $p$-methoxycinnamic acid.

\subsection{Hepatoprotective Effect of $p-M C A$}

Phenylpropanoids are well known in the literature as the plant metabolites exhibiting hepatoprotective activity $[49,50]$ (Table 2). However, Lee and coworkers studying the relationship between the chemical structure of phenylpropanoids and their hepatoprotective activity have proven that not only the $\alpha, \beta$-unsaturated ester moiety, but also the presence 
of the methoxy group in the para position of benzene ring are crucial pharmacophores for this therapeutic property [51]. In vitro tests carried out on rat hepatocytes injured by $\mathrm{CCl}_{4}$ showed that $p$-MCA and isoferulic acid exhibit an equipotency effect similar to silybin [52] when used as a supplementary treatment for liver disease at a lower concentration, even 10-50 times lower. Moreover, as a comparison it has been presented that unsubstituted or hydroxy substituted phenylpropanoids possess much weaker hepatoprotective properties. The mechanism of the hepatoprotective activity of $p$-MCA was studied on hepatic levels of glutathione (GSH) and hepatic enzymes related to the GSH redox pathway. While the silybin used as a reference substance at a dose of $50 \mu \mathrm{M}$ maintained the GSH concentration at a level of half of its concentration in the control sample, $p$-MCA at a concentration of $5 \mu \mathrm{M}$ significantly preserved the level of total GSH and prevented a decrease in GSH levels by $\mathrm{CCl}_{4}$. According to the authors' observations, $p$-MCA also preserved the activity of glutathione disulfide reductase (GR) and glutathione-S-transferase (GST), which is important for maintaining normal cell homeostasis.

Table 2. Hepatoprotective effect of $p$-methoxycinnamic acid on injured rat hepatocytes.

\begin{tabular}{|c|c|c|c|c|c|}
\hline & Control & $\begin{array}{c}\mathrm{CCl}_{4}^{-} \\
\text {Intoxicated Rat } \\
\text { Hepatocytes }\end{array}$ & $p-\mathrm{MCA}+\mathrm{CCl}_{4}$ & Silybin & Ref. \\
\hline Concentration $(\mu \mathrm{M})$ & - & - & 5 & 50 & \multirow{7}{*}[51]{} \\
\hline Total GSH (nmol/mg prot.) & $59.74 \pm 2.13$ & $9.44 \pm 1.02$ & $13.32 \pm 0.68$ & $26.51 \pm 4.23$ & \\
\hline Reduced GSH (nmol/mg prot.) & $41.39 \pm 1.92$ & $4.08 \pm 0.08$ & $10.45 \pm 0.83$ & $21.65 \pm 1.46$ & \\
\hline GSSG/total GSH & 0.307 & 0.621 & 0.235 & 0.301 & \\
\hline $\begin{array}{l}\text { Glutathione peroxidase (GPx) } \\
\text { (nmol/mg protein/min) }\end{array}$ & $1.416 \pm 0.018$ & $0.812 \pm 0.032$ & $0.831 \pm 0.049$ & $0.891 \pm 0.024$ & \\
\hline $\begin{array}{l}\text { Glutathione disulfide reductase (GR) } \\
\text { (nmol/mg protein } / \mathrm{min})\end{array}$ & $91.74 \pm 11.70$ & $48.73 \pm 3.37$ & $68.83 \pm 1.24$ & $60.01 \pm 3.73$ & \\
\hline $\begin{array}{l}\text { Glutathione-S-transferase (GST) } \\
\text { (nmol/mg protein/min) }\end{array}$ & $1.755 \pm 0.135$ & $1.110 \pm 0.036$ & $1.466 \pm 0.177$ & $1.134 \pm 0.086$ & \\
\hline $\begin{array}{l}\text { Alkaline phosphatase (ALP) } \\
(\mu \mathrm{mol} / \mathrm{L} \text { min })\end{array}$ & $107.21 \pm 7.36$ & $161.03 \pm 12.51$ & $150.33 \pm 9.71$ & - & \multirow{3}{*}{ [53] } \\
\hline $\begin{array}{l}\text { Gamma-glutamyl transpeptidase } \\
(\gamma \text {-GTP })(\mu \mathrm{mol} / \mathrm{L} \mathrm{min})\end{array}$ & $8.67 \pm 0.24$ & $25.32 \pm 1.27$ & $5.86 \pm 2.14$ & - & \\
\hline $\begin{array}{l}\text { Alanine aminotransferase (ALT) } \\
(\mu \mathrm{mol} / \mathrm{L} \mathrm{min})\end{array}$ & $33.53 \pm 1.23$ & $64.19 \pm 1.36$ & $14.12 \pm 1.00$ & - & \\
\hline
\end{tabular}

Similar observations were reported by Fernández-Martinez et al., who studied cinnamic acid derivatives' activity in preventing experimental $\mathrm{CCl}_{4}$-induced liver damage [53]. They also confirmed significant hepatoprotective activity of $p$-MCA in primary cultures of rat hepatocytes among all tested phenylpropanoids. It turned out $p$-MCA exhibited the most protective effect on the plasmatic enzyme activities of alkaline phosphatase (ALP), gamma-glutamyl transpeptidase ( $\gamma$-GTP), and alanine aminotransferase (ALT) in models of rats intoxicated with $\mathrm{CCl}_{4}$. The authors suggest that for this phenomenon responsible different than the antioxidant mechanism and indicate on such pharmacological targets like anti-NF- $\mathrm{kB}$ and anti-5-lipooxygenase activities.

\subsection{Antidiabetic and Antihyperglycemic Activity of $p-M C A$}

Phenolic acids are known in the literature as natural compounds with potential antidiabetic activity. Molecules belonging to that group have shown during in vitro and in vivo tests that they are able to increase glucose uptake and glycogen synthesis as well as improve glucose and lipid profiles of type 2 diabetes patients [54,55]. Interest in the antidiabetic activity of $p$-MCA has been accelerated in recent years. The insulinotropic and antihyperglycemic properties of $p$-MCA published so far are presented in Table 3. 
Table 3. Antihyperglycemic and insulinotropic activity of $p$-MCA.

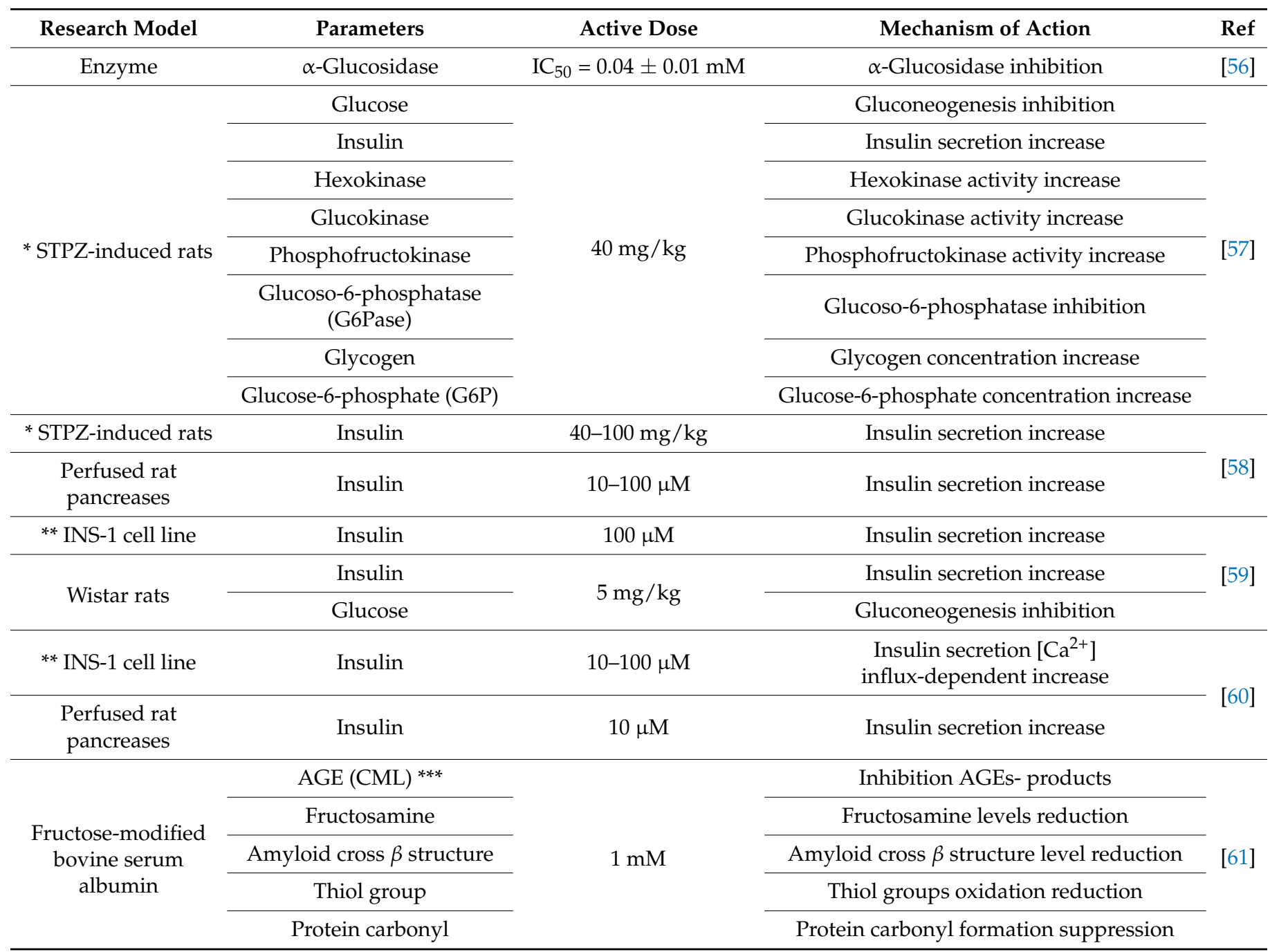

*STPZ—streptozotocin; ** INS-1—rat insulinoma cell line; ${ }^{* * *}$ AGE-advanced glycation end products; CML-N ${ }^{\varepsilon}$-(carboxymethyl)lysine.

Adisakwattana et al. proved that, isolated from the rhizomes of Kaempferia galanga, $p$-MCA and its ethyl ester act as effective $\alpha$-glucosidase inhibitors. Using the positive inhibitor 1-deoxynorjirimycin, they determined that the effective dose of $p$-MCA toward $\alpha$-glucosidase $\left(\mathrm{IC}_{50}=0.044 \pm 0.006 \mathrm{mM}\right)$ is 100 -fold lower than the active dose of the compound used as the control $\left(\mathrm{IC}_{50}=5.60 \pm 0.42 \mathrm{mM}\right)$. Among tested cinnamic acid derivatives, $p$-MCA turned out to be the most active inhibitor of $\alpha$-glucosidase from baker's yeast as well as $p$-methoxycinnamic acid ethyl ester $\left(\mathrm{IC}_{50}=0.05 \pm 0.03 \mathrm{mM}\right)$. Whereas the first one acted as a noncompetitive inhibitor of $\alpha$-glucosidase, the latter one was established as a competitive inhibitor. Moreover, obtained results suggest that the presence of a hydroxy or methoxy group at the para position is necessary to enhance $\alpha$-glucosidase inhibitory activity; however, methoxylated phenylpropanoid at this position is almost 5-fold more active than corresponding hydroxyderivative [56].

The same research group next studied the antihyperglycemic effects of $p$-MCA on plasma glucose and insulin concentration as well as the activities of hepatic glucoseregulating enzymes and hepatic glycogen content in normal and streptozotocin (STZ)induced diabetic rats. The normal and diabetic rats were fed $p$-MCA at a dose of $40 \mathrm{mg} / \mathrm{kg}$ for 4 weeks and it was observed that this acid significantly influenced the activity of the liver enzymes in rats with streptozotocin-induced (STZ) diabetes. While the activity of hexokinase, glucokinase, and phosphofructokinase was significantly raised in diabetic rats after chronic administration of $p-\mathrm{MCA}$, in normal ones their levels did not change. It is 
worth noting that a single administration of this acid to both tested groups of rats reduced plasma glucose concentrations within $30 \mathrm{~min}$. Moreover, an increased glycogen storage in diabetic rats by $80 \%$ was estimated. The authors suggest that antihyperglycemic activity is the effect of increased glycolysis and inhibited gluconeogenesis in the liver [57].

Insulinotropic activity of $p$-MCA was further studied in normal and streptozotocininduced diabetic rats as well as its effect on insulin secretion from perfused rat pancreases and on intracellular calcium in the pancreatic $\beta$-cell line [58]. According to the authors, for normal rats, the greatest decrease in glucose concentration and increase in plasma insulin concentration were recorded for animals treated orally with 40 and $100 \mathrm{mg} / \mathrm{kg}$ $p$-MCA and these effects were observed $60 \mathrm{~min}$ after administration. In diabetic rats, a significant decrease in plasma glucose concentrations was observed, especially at a dose of $100 \mathrm{mg} / \mathrm{kg} p-\mathrm{MCA}$, and this effect maintained up to $3 \mathrm{~h}$ during fasting. One week after induction of diabetes, insulin deficiency was observed in rats, and its concentration was 2.3 times lower than in normal rats. A greater increase in insulin concentration was noted in rats $1 \mathrm{~h}$ after administration of a $40 \mathrm{mg} / \mathrm{kg}(730.9 \pm 113.9 \mathrm{pg} / \mathrm{mL})$ dose of $p$-MCA than after supplementation with $100 \mathrm{mg} / \mathrm{kg}(645.2 \pm 89.5 \mathrm{pg} / \mathrm{mL})$. These insulin values increased by 2.0 and 1.76 times, respectively, over the course of one hour. In the oral glucose tolerance test, authors confirmed that the plasma glucose concentrations were significantly decreased in both normal and diabetic rats treated with $p$-MCA. Moreover, the insulinotropic activity of $p$-MCA has been reported based on data obtained from perfused rat pancreases. Acid stimulated insulin secretion in the presence of $5.5 \mathrm{mM}$ glucose and enhanced insulin secretion in the presence of $10 \mathrm{mM}$ glucose. These findings suggest that $p$-MCA may find application to patients with diabetes mellitus who have defects in the response of insulin secretion to glucose and nutrient stimulation. The relationship between the structure of cinnamic acid and its derivatives were evaluated by the examination of effects of activity these compounds had on the insulin secretion and intracellular calcium $\left[\mathrm{Ca}^{2+}\right]_{\mathrm{i}}$ in the pancreatic $\beta$-cell line (INS-1) [59]. It has been confirmed that presence of $p$-methoxy and $m$-hydroxy residues on cinnamic acid are crucial substituents for effective insulin releasing. However, only $p$-MCA was indicated as an agent that can be useful for controlling postprandial hyperglycemia in diabetic patients because $m$-hydroxycinnamic acid undergoes a rapid onset and short duration of action in animal models. In comparison, $p$-MCA is able to produce more prolonged action that maintains the lowering of plasma glucose by increasing the insulin secretion from pancreatic $\beta$-cells.

The confirmed action of $p$-MCA on the regulation of blood glucose and insulin levels prompted the authors of the above-described studies to determine the mechanism by which this acid stimulates insulin secretion [60]. Adisakwattana et al. confirmed that $p$-MCA influences insulin secretion from rat pancreatic $\beta$-cells by increasing the influx of $\left[\mathrm{Ca}^{2+}\right]_{\mathrm{i}}$ in INS-1 cells via the L-type calcium channels that can be reinforced by synergistic action with the sulfonylurea antidiabetic agent glibenclamide. They also studied the antiglycation properties of cinnamic acid and its derivatives in a bovine serum albumin (BSA)/fructose system [61].

Compared to the drugs used in the treatment of diabetes, such as sulfonylurea derivatives, metformin, $\alpha$-glucosidase inhibitors, or glitazones, $p$-MCA seems to be a safer agent of treating patients with type 2 diabetes. This natural compound did not show in the in vivo tests activity to induce hypoglycemia or secondary insulin secretory insufficiency. This acid not only increases hepatic glycogen storage, but also increases the ability of the impaired pancreas to secrete insulin in the case of diabetes. The inhibition of the formation of advanced protein glycation products observed during $p$-MCA activity tests may indicate its protective effect and therapeutic activity not only in the case of diabetes, but also in other degenerative diseases, including those related to the nervous, skeletal, and circulatory systems. 


\subsection{Anticancer and Chemopreventive Activity of $p-M C A$}

One of the first papers describing the antitumor potential of $p$-MCA was published in 2000 by Hudson et al. and presented the results of an investigation of the activity of the phenol fraction of brown rice on the proliferation and growth of human breast and colon cancer cells (Table 4) [6]. The authors documented the potential inhibitory properties of phenolic acids on colon and breast cancers, including $p$-MCA extracted from cooked rice bran and brown rice. They indicated that phenols might be a good candidate nutraceutical with colon or particularly breast cancer chemopreventive activity. The $p$-MCA obtained from brown rice and applied in a concentration of $50 \mu \mathrm{M}$ showed the activity to inhibit the proliferation of colon tumor cells of the HT 29 line and human colon cells of the HCEC line, and the obtained results were similar to those observed for the positive controls genistein $(30 \mu \mathrm{M})$ and tricine $(50 \mu \mathrm{M})$. It was also reported that $p$-MCA interfered with the colony formation of colon cancer cell line SW480. The mechanism of anticancer action of $p$-MCA toward human colon adenocarcinoma cell lines was evaluated by Gunasekaran et al. They confirmed that this phenylpropanoid induces apoptosis via an increase in caspase 3 and caspase 9 activities, resulting in the release of cytochrome $C$ to cytosol [62].

The chemopreventive activity of $p$-MCA has been evaluated in preclinical models of colon cancer against 1,2-dimethylhydrazine-induced (DMH) rat colon carcinogenesis [63]. Supplementation of rats at doses of 20,40, and $80 \mathrm{mg} / \mathrm{kg} \mathrm{b.wt} /$ day for 16 weeks resulted in significant inhibition of the formation of aberrant crypt foci and its multiplication and prevented alterations in DMH-induced circulatory and tissue oxidative stress as well as preneoplastic changes. The therapeutic effects were especially visible after supplementation of rats with a dose of $40 \mathrm{mg} / \mathrm{kg} \mathrm{b.wt}$. than at the two other tested doses. This amount is very low in comparison with therapeutic doses for other studied so far phenylpropanoids. Moreover, the estimated active anticancer dose of $p$-MCA in rats is equal to $6.4 \mathrm{mg} / \mathrm{kg}$ b.wt. in humans [64]. Therefore, authors marked that this dose cannot be directly correlated with the daily dietary/rice intake by human beings. In this case, daily supplementation of $p$ MCA is necessary. The same dose was found to restore the histological changes induced by $\mathrm{DMH}$ and modulate the phase I and phase II enzymes. The $p$-MCA reduced the increased $\mathrm{DMH}$ activity of phase I enzymes from microsomal fractions, including cytochrome P450, cytochrome b5, cytochrome P4502E1, cytochrome b5 NADPH reductase, and cytochrome P450 NADH reductase compared to groups treated with DMH alone. In the case of phase II enzymes from the cytosolic fractions, exposure to DMH resulted in a significant reduction in the activity of the enzymes glutathione S-transferase (GST), DT-diaphorase (DTD), UDPglucuronyl transferase (UDPGT), and gamma glutamyl transferase (GGT) compared to the control group [65].

Table 4. Chemopreventive and cytotoxic activity of $p$-MCA.

\begin{tabular}{|c|c|c|c|c|}
\hline Molecule & Research Model & Active Dose & Mechanism of Action & Ref \\
\hline \multirow{6}{*}{$p$-MCA } & SW480 cell line & $200 \mu \mathrm{M}$ & Anticlonogenic activity & [6] \\
\hline & HCT-116 cell line & $\mathrm{IC}_{50}=10.25 \pm 0.94 \mu \mathrm{M}$ & \multirow{4}{*}{ Induction of apoptosis } & \multirow{4}{*}[62]{} \\
\hline & HT-29 cell line & $\mathrm{IC}_{50}=11.23 \pm 1.02 \mu \mathrm{M}$ & & \\
\hline & COLO320 cell line & $\mathrm{IC}_{50}=12.32 \pm 0.81 \mu \mathrm{M}$ & & \\
\hline & NCM460 cell line & $\mathrm{IC}_{50}=137.28 \pm 2.37 \mu \mathrm{M}$ & & \\
\hline & ${ }^{*} \mathrm{DMH}$-induced Wistar rats & $40 \mathrm{mg} / \mathrm{kg}$ & $\begin{array}{l}\text { Induction of apoptosis } \\
\text { Anti-inflammatory effect } \\
\text { Antiproliferative effect } \\
\text { Antiangiogenic effect }\end{array}$ & $\begin{array}{c}{[7]} \\
{[65]} \\
{[63]}\end{array}$ \\
\hline
\end{tabular}

\footnotetext{
*DMH-1,2-dimethylhydrazine.
} 
Supplementation with $p$-MCA decreased the size and incidence of tumors in the colon of carcinogen-treated rats [7]. It was shown that this phenylpropanoid acid in a dose of $40 \mathrm{mg} / \mathrm{kg} \mathrm{b.wt}$. exhibited ameliorating anticancer effects by altering multiple processes, including proliferation, angiogenesis, invasion, and induction of cell death in DMH-induced rat colon carcinogenesis. However, the molecular mechanism of the action of $p$-MCA still needs more advanced studies as it seems that the putative antioxidant, anti-inflammatory, and anticarcinogenic properties are crucial to this point [63].

\subsection{Neuroprotective Activity of $p-M C A$}

In 2000, the research group of Kim evaluated the neuroprotective potential of phenylpropanoids isolated from Scrophularia buergeriana MIQ roots in vitro. The activities of compounds being the constituents of the extract were defined by the quantitative measure of the release of LDH into the culture media from primary cultures of rat cortical cells injured with glutamate. The obtained results indicate that $p$-methoxycinnamic acid possesses strong neuroprotectant activity. For this acid, the highest percentage of cell viability among tested phenylpropanoids on the level of $78 \%$ was recorded at a concentration of $1 \mu \mathrm{M}$ [66].

In the following years, the research had been extended. Using the same culture system, the structure-activity relationship of isolated phenylpropanoids on glutamate-induced neurotoxicity was analyzed. This time, $p$-MCA also exhibited the highest potency of neuroprotective activity in the group of tested phenylpropanoids. The operating effectiveness was especially visible when $p$-MCA was added before and not after glutamate-induction of neurotoxicity. The mechanism of the action of $p$-MCA was next evaluated in the assays performed with two excitotoxins, $N$-methyl-D-aspartic acid (NMDA) and kainic acid (KA), which were used for induction of selective receptor-mediated neurotoxicity in primary cultures of rat cortical cells. It was confirmed that although $p$-MCA showed neuroprotection for both excitotoxins used, it was more effective in protecting cells from NMDA-induced toxicity than from KA-induced neurotoxicity. This finding was supported by separate studies that determined the $\left[\mathrm{Ca}^{2+}\right]_{i}$ and the content of nitric oxide. Moreover, $p$-MCA also inhibited the binding of [propyl-2,3- $\left.{ }^{3} \mathrm{H}\right]$-CGP39653 and $\left[2-{ }^{3} \mathrm{H}\right]$-glycine to their respective binding sites on rat cortical membranes. However, even at a higher concentration this inhibition was not complete [67].

Further research in this area attempted to determine whether phenolic acids and their methoxy derivatives could inhibit the process of amnesia, which is one of the common ailments that occurs in diseases of the nervous system. The research was carried out on mice with amnesia induced in vivo by scopolamine. Among the tested phenylpropanoids, $p$-MCA and isoferulic acid significantly improved the deficit of memory induced by scopolamine, indicating that $\alpha, \beta$-unsaturated carboxyl moiety and the para-methoxy group in phenylpropanoids might be important elements in their cognition-enhancing activity. The use of these compounds before induction of memory loss completely prevented amnesia, while their administration after induction with scopolamine resulted in the regression of lesions by $60 \%$. In both cases, the determined active doses of acids were $1 \mathrm{mg} / \mathrm{kg}$ body weight, and this effect was possible after a five-day supplementation [64].

A lack of evidence for the therapeutic effect of $p$-MCA in chronic memory deficit encouraged Rijal and coworkers to study this acid and its ethyl ester against a chronic model of cognitive dysfunction induced in rats by administering $\mathrm{AlCl}_{3}(10 \mathrm{mg} / \mathrm{kg})$. Treatment with these compounds showed a significant improvement in spatial memory makers and altered hippocampal $\mathrm{AChE}$ activity in rats with cognitive dysfunction. The improvement in memory and cognitive parameters was attributed to the neuronal-protective antioxidant activity of $p$-MCA, and biochemical effects such as AChE regulation only support the neurotherapeutic properties of $p$-MCA in aluminum-induced dementia. Moreover, the authors described the superiority of ethyl $p$-methoxycinnamate $(50-100 \mathrm{mg} / \mathrm{kg}$ ) over $p$ MCA due to better bioavailability of this derivative in the body and better regulation of AChE enzymes [68]. 


\subsection{Antimicrobial Activity of $p-M C A$}

Increasing drug resistance of microorganisms has led to the search for new effective agents based on compounds of natural origin. Since it was reported that cinnamic acid exhibits antimicrobial activity, many research groups have started evaluating the relationship between the structure of phenylpropanoids and their microbiological effects. Narasimhan et al. performed in vitro tests evaluating the biological activity of a number of cinnamic acid derivatives against selected strains of microorganisms. They found that while cinnamic acid exhibited a weak antibacterial effect against most of Gram-negative and Gram-positive species of bacteria with minimum inhibitory concentration (MIC) values ranging from $270 \mu \mathrm{M}$ to $6.75 \mathrm{mM}, p$-MCA showed much higher activity toward the same species with active doses between $50.4 \mu \mathrm{M}$ and $449 \mu \mathrm{M}$. This acid exhibited higher inhibition against fungal species in comparison to bacteria (Table 5) $[10,69,70]$. $p$ Methoxycinnamic acid turned out to be the most active substance of yuzu (Citrus junos hort. Ex Tanaka) seed extract and is responsible for its antimicrobial effect. $p$-MCA acid and other phenolic compounds are also responsible for the antibacterial and antifungal properties of the extract of roots of Dendranthema zawadskii var latilobum Kitamura. The 4-methoxylated derivative of cinammic acid showed a moderately broad spectrum of antibacterial activity against both Gram-positive and Gram-negative bacteria [22], whereas its antibacterial activity was significant against cariogenic oral streptococci Streptococcus mutans and Streptococcus sobrinu [29]. Structurally related to cinnamic acid, phytochemicals were assessed as antimicrobial agents toward Escherichia coli, Staphylococcus aureus, and Enterococcus hirae by Malheiro and coworkers. In the case of $p$-MCA, a tested maximum concentration $25 \mathrm{mM}$ turned out to be too low to establish a MIC and minimum bacterial concentration (MBC). However, its effect on bacterial growth dynamic was clearly visible. $p$-MCA and its tested derivatives were able to affect bacterial growth at $5 \mathrm{mM}$ either increasing doubling time or increasing the duration of the lag phase. The authors also indicated that the mode of action of these phytochemicals depends on the concentration of undissociated acid. It was established that with a lower $\mathrm{pH}$ the antimicrobial activity tends to increase since the concentration of undissociated phenolic acids is higher, making them more soluble in cytoplasmic membranes. Moreover, studied molecules were able to inhibit quorum sensing [71].

Based on these preliminary results, Cheng et al. studied the activity of 4-dimethylamin ocinnamic acid (DCA) and $p$-MCA toward Chromobacterium violaceum [72]. Both compounds were identified as potential quorum-sensing (QS) and biofilm inhibitors. It was observed that they reduced the level of $\mathrm{N}$-decanoyl-homoserine lactone (C10-HSL) at concentrations of $100 \mu \mathrm{g} / \mathrm{mL}$ and $200 \mu \mathrm{g} / \mathrm{mL}$, respectively, and inhibited production of virulence factors. They effectively inhibited the expression of coil, leading to a decrease in C10-HSL and eventually a decrease in its binding to the transcription regulatory protein CviR in $C$. violaceum. During the study of the mechanism of antibacterial action of cinnamic acid and $p-\mathrm{MCA}$, it was proven that these compounds effectively reduced the production of chitinase and the expression of its regulatory gene chiA, which limits the invasiveness and adaptability of the $C$. violaceum growing environment. $p$-MCA increased the sensitivity of biofilms to tobramycin by introducing changes in the structure of the cell membrane. In addition, it has been proven that $p$-MCA reduces the level of cellular metabolites, including L-methionine, ethanolamine, D-proline, $N$-acetyl-L-leucine, L-norleucine, L-valine, and L-ornithine, and increases the levels of L- citrulline and ophthalmate [72]. 
Table 5. Antimicrobial and antifungal activity of $p$-MCA.

\begin{tabular}{|c|c|c|}
\hline \multicolumn{3}{|c|}{ Gram-Positive Bacteria } \\
\hline Microorganisms & Active Dose of $p$-MCA & Ref. \\
\hline Bacillus subtilis & MIC $203 \mu \mathrm{M}$ & [69] \\
\hline Staphylococcus aureus & MIC $203 \mu \mathrm{M}$ & [69] \\
\hline Micrococcus luteus & MIC $80 \mu \mathrm{g} / \mathrm{mL}$ & [10] \\
\hline Staphylococcus aureus & $\mathrm{MIC} 60 \mu \mathrm{g} / \mathrm{mL}$ & [10] \\
\hline Bacillus subtilis & $25-100 \mu \mathrm{g} / \mathrm{disc}$ & [22] \\
\hline Staphylococcus aureus & 25-100 $\mu \mathrm{g} / \mathrm{disc}$ & [22] \\
\hline Streptococcus mutans & MIC $352 \mu \mathrm{g} / \mathrm{mL}$ & [29] \\
\hline Streptococcus sobrinus & $\mathrm{MIC} 470 \mu \mathrm{g} / \mathrm{mL}$ & [29] \\
\hline Staphylococcus aureus & $\begin{array}{l}\mathrm{MIC}>25 \mathrm{mM} \\
\mathrm{MBC}>25 \mathrm{mM}\end{array}$ & [71] \\
\hline Enterococcus hirae & $\begin{array}{l}\mathrm{MIC}>25 \mathrm{mM} \\
\mathrm{MBC}>25 \mathrm{mM}\end{array}$ & [71] \\
\hline \multicolumn{3}{|c|}{ Gram-Negative Bacteria } \\
\hline Microorganisms & Active Dose of $p$-MCA & Ref. \\
\hline Escherichia coli & MIC $164 \mu \mathrm{M}$ & [69] \\
\hline Escherichia coli & MIC $50 \mu \mathrm{g} / \mathrm{mL}$ & [10] \\
\hline Salmonella enteritidis & MIC $60 \mu \mathrm{g} / \mathrm{mL}$ & [10] \\
\hline Escherichia coli & $25-100 \mu \mathrm{g} / \mathrm{disc}$ & [22] \\
\hline Shigella sonnei & $25-100 \mu \mathrm{g} /$ disc & [22] \\
\hline Chromobacterium violaceum & $200 \mu \mathrm{g} / \mathrm{mL}$ & [72] \\
\hline Escherichia coli & $\begin{array}{l}\mathrm{MIC}>25 \mathrm{mM} \\
\mathrm{MBC}>25 \mathrm{mM}\end{array}$ & {$[71]$} \\
\hline \multicolumn{3}{|c|}{ Fungi } \\
\hline Microorganisms & Active Dose of $p$-MCA & Ref. \\
\hline Aspergillus niger & MIC $50.4 \mu \mathrm{M}$ & [69] \\
\hline Candida albicans & MIC $50.4 \mu \mathrm{M}$ & [69] \\
\hline
\end{tabular}

\section{Recent Developments in Production of Lipid Derivatives of $p$-MCA}

In 2006, Weber's team presented results of the lipophilization process of $p$-MCA by the transesterification reaction of methyl $p$-methoxycinnamate with oleic alcohol (cis9-octadecan-1-ol) (Figure 2). The reason for the undertaken research was the fact that long-chain esters of $p$-MCA may be used in the food industry as food additives. During studies, the activity of three commercially available immobilized preparations of lipases, Novozym 435, Lipozyme RM IM, and Lipozyme TL IM, were tested. Enzymatic reactions with these lipases were carried out at $80{ }^{\circ} \mathrm{C}$ for $72 \mathrm{~h}$. The highest degree of $p$-MCA conversion of $92 \%$ was obtained in the reaction catalyzed by lipase B from $C$. antarctica (Novozym 435). Less activity (60\% conversion) was shown by the lipase from $R$. miehei (Lipozyme RM IM), while the lipase from T. lanuginosus (Lipozyme TL IM) was essentially not able to catalyze a transesterification reaction [73]. 
<smiles>COC(=O)/C=C/c1ccc(OC)cc1</smiles>

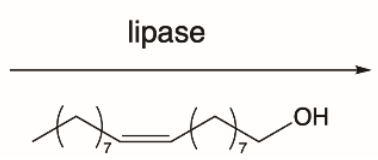<smiles>COc1ccc(/C=C/C(=O)OCCCCC(C)(C)C)cc1</smiles>

Figure 2. Transesterification of methyl methoxycinnamate with cis-9-octadecen-1-ol.

Another process of enzymatic lipophilization of $p$-MCA was described by Lee and coworkers, who carried out the synthesis of its ester derivative in reaction with 2-ethylhexanol (Figure 3). Octyl methoxycinnamate (OMC) was obtained via a direct esterification reaction between the above-mentioned substrates at a temperature of $80^{\circ} \mathrm{C}$ using Novozym 435 as a biocatalyst. The highest level of substrate conversion (90\%) was obtained in 1 day and this high conversion was favored by the use of nonpolar organic solvents as the reaction medium. The OMC ester obtained as a product is a compound that effectively absorbs UV$B$ rays, which is why it has been widely used in the cosmetics industry as a nonallergenic sunscreen [74].<smiles>COC(=O)/C=C/c1ccc(OC)cc1</smiles>
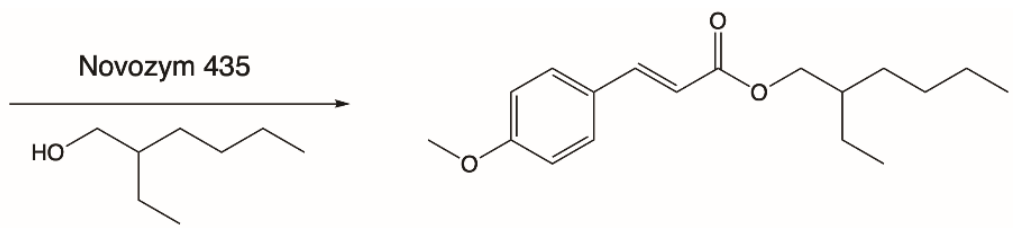

Figure 3. Enzymatic synthesis of octyl methoxycinnamate (OMC).

The optimization of the enzymatic production of OMC was also carried out a few years later by Kumar. Using the lipase from Rhizopus oryzae as a biocatalyst, he obtained OMC with a slightly higher degree of conversion on the level of $91.3 \%$ in the reaction of $p$-MCA with 2-ethylhexanol. In the esterification process, cyclooctane was applied as the reaction solvent. The synthesis process, carried out on an enlarged scale at a temperature of $45^{\circ} \mathrm{C}$, resulted in a high yield of octyl 4-methoxycinnamate $(88.6 \%)$ after $96 \mathrm{~h}$ of reaction. The obtained product was then subjected to further tests, which confirmed that it exhibited higher antioxidant activity compared to ascorbic acid and the free form of $p$-MCA acid as well as high antimicrobial activity against certain strains of bacteria, yeasts, and fungi such as: Escherichia coli, Klebsiella pneumonia, Salmonella typhi, Staphylococcus aureus, Candida albicans, Aspergillus niger, Alternariasolani and Fusarium oxysporum [75].

A novel synthetic strategy for the production of a long chain ester of $p$-MCA was presented by Borges's research group [76]. They obtained new trans-tetradecyl-3-(4methoxyphenyl)propenoate in the reaction of tetradecyl monomalonate with 4-methoxyben zaldehyde via Knoevenagel condensation (Figure 4). The ester synthesized with a high yield of $95 \%$.

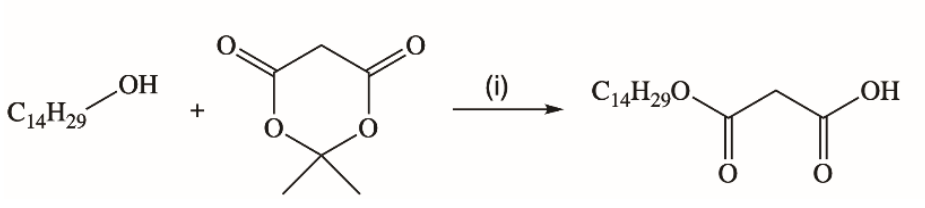<smiles>CCCCCCOC(=O)/C=C/c1ccc(OC)cc1</smiles>

Figure 4. Synthesis of long-chain alkyl p-methoxycinnamate. Reaction conditions: (i) toluene, reflux, $4 \mathrm{~h}$ (ii) 4 methoxybenzaldehyde, pyridine, $\beta$-alanine.

Extensive studies on the chemical and enzymatic production of phenolipids and their biological activities were performed using phospholipids, which are characterized by unique physicochemical properties [77-83]. In our research group, we developed the biotechnological method of synthesis of phospholipid derivatives of $p$-MCA [84]. In the enzymatic interesterification reaction of egg yolk phosphatidylcholine (PC) with ethyl 
$p$-methoxycinnamate (Ep-MCA), catalyzed by Novozym 435 under optimized parameters, after three days $p$-methoxycinnamoylated lysophosphatidylcholine ( $p$-MCA-LPC) and $p$-methoxycinnamoylated phosphatidylcholine ( $p$-MCA-PC) were obtained in isolated yields of $32 \%$ and $3 \%(w / w)$, respectively (Figure 5$)$. Based on the analysis of formed products via thin-layer chromatography (TLC) and high-performance liquid chromatography (HPLC), the pathway of possible changes occurring during the reaction of enzymatic interesterification was also proposed [84].

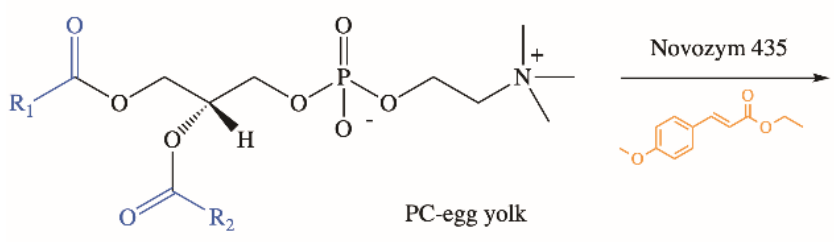

$\mathrm{R}_{1}, \mathrm{R}_{2}=$ fatty acids

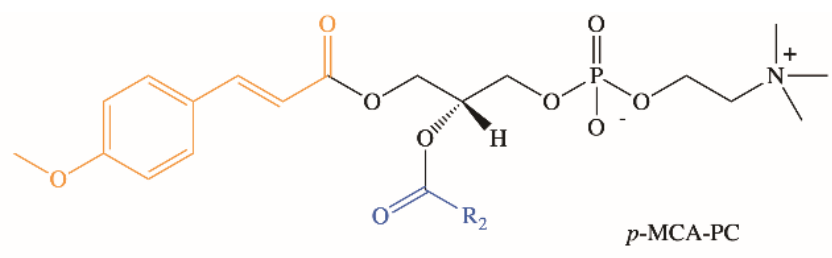

$+$<smiles>COc1ccc(/C=C/C(=O)OC[C@H](O)COP(=O)([O-])OCC[N+](C)(C)C)cc1</smiles>

Figure 5. Enzymatic synthesis of phospholipid derivatives of $p$-MCA.

\section{Conclusions and Future Perspectives}

The data summarized above present $p$-MCA acid as a molecule that is widespread in the plant kingdom and possesses noteworthy and useful biological properties. Described literature data provide evidence for the protective role of $p$-MCA in degenerative diseases, leaving no doubt that this dietary compound exhibits very high therapeutic and nutraceutical potential. This biomolecule plays the role of a natural antioxidant and also shows indirect antioxidant activity by inducing endogenous protective enzymes and positive regulatory effects on signaling pathways. Compared to other phenylpropanoids, its prohealth properties are significantly valuable. The main advantage of the industrial application of $p$-MCA is its nontoxicity and metabolizing ability via natural microbes.

The wide variety of health benefits of $p$-MCA as well as other phenolic acids of plants make them attractive for industry. The intake and the use of these compounds as functional ingredients to enrich foods have been increasing in order to provide health benefits to consumers. Foods rich in phenolic acids have been considered as functional foods and a significant growing interest for this type of product from scientists and industry has been observed since 2000 .

Phenolic compounds have been used so far in the food industry mainly as natural preservatives but also as agents for enhancing the organoleptic, color, and sensory qualities. In the case of $p$-MCA it is also worth noting that its antioxidant activity is on the level of $70-80 \%$ of antioxidant activity of commercially used synthetic food preservatives like butylated hydroxyanisole (BHA) and butylated hydroxytoluene (BHT). That makes this compound very promising as a new natural preservative, especially when we take into account the toxicity of synthetic antioxidants [10]. In addition to its use as a natural antioxidant and therapeutic agent, it could also find use in the food industry as an antimicrobial agent. Nakazono et al. proved that $p$-MCA exhibits greater antibacterial activity than the preservatives commonly used in food production, such as sodium benzoate, benzoic acid, or gallic acid, against bacteria inhabiting the surfaces of production equipment in the food industry, including Micrococcus luteus, Staphylococcus aureus, Escherichia coli and Salmonella enteritidis [10].

Despite such promising results, detailed molecular studies of the biological targets of this acid and other phenolic compounds are still needed using in vitro and in vivo models. 
Studies geared toward the development of efficient and environmentally friendly methods of production of their lipid derivatives, which, as presented above, may solve the problem of their low bioavailability in the human body, are also needed. This seems to be the future trend in this area as well as the production of valuable formulations based on the use of nanotechnology to overcome problems related to the instability of these compounds, which will be a promising strategy to assure bioavailability and to help overcome problems regarding food processing and ingestion.

Author Contributions: Conceptualization, A.G.; writing-original draft preparation, A.G. and A.P.; writing-review and editing, A.G. and A.P.; visualization, A.G.; supervision, A.G. All authors have read and agreed to the published version of the manuscript.

Funding: This research received no external funding.

Institutional Review Board Statement: Not applicable.

Informed Consent Statement: Not applicable.

Data Availability Statement: Data is contained within the article.

Conflicts of Interest: The authors declare no conflict of interest.

\section{References}

1. Bento-Silva, A.; Koistinen, V.M.; Mena, P.; Bronze, M.R.; Hanhineva, K.; Sahlstrø, S.; Kitryte, V.; Moco, S.; Aura, A.M. Factors affecting intake, metabolism and health benefits of phenolic acids: Do we understand individual variability? Eur. J. Nutr. 2020, 59, 1275-1293. [CrossRef] [PubMed]

2. Andrade, P.B.; Leitão, R.; Seabra, R.M.; Oliveira, M.B.; Ferreira, M.A. 3,4-Dimethoxycinnamic acid levels as a tool for differentiation of Coffea canephora var robusta and Coffea arabica. Food Chem. 1998, 61, 511-514. [CrossRef]

3. Sobolev, V.S.; Horn, B.W.; Potter, T.L.; Deyrup, S.T.; Gloer, J.B. Production of stilbenoids and phenolic acids by the peanut plant at early stages of growth. J. Agric. Food Chem. 2006, 54, 3505-3511. [CrossRef] [PubMed]

4. Sytar, O. Phenolic acids in the inflorescences of different varieties of buckwheat and their antioxidant activity. J. King Saud Univ. Sci. 2014, 27, 136-142. [CrossRef]

5. Wang, S.L.; Zhou, L.; Zhu, A.X.; Yang, X.S.; Li, Q.J.; Yang, J. A new macrocyclic phenolic glycoside from Sorghum vulgare root. China J. Chin. Mater. Med. 2020, 45, 3689-3693.

6. Hudson, E.A.; Dinh, P.A.; Kokobun, T.; Simmonds, M.S.; Gescher, A. Characterization of potentially chemopreventive phenols in extracts of brown rice that inhibit the growth of human breast and colon cancer cells. Cancer Epidemiol. Biomark. Prev. 2000, 9 , 1163-1170.

7. Sivagami, G.; Karthikkumar, V.; Balasubramanian, T.; Nalini, N. The modulatory influence of $p$-methoxycinnamic acid, an active rice bran phenolic acid, against 1,2-dimethylhydrazine-induced lipid peroxidation, antioxidant status and aberrant crypt foci in rat colon carcinogenesis. Chem. Biol. Interact. 2012, 196, 11-22. [CrossRef]

8. Kargutkar, S.; Brijesh, S. Anti-inflammatory evaluation and characterization of leaf extract of Ananas comosus. Inflammopharmacology 2018, 26, 469-477. [CrossRef]

9. Otálvaro, F.; Jitsaeng, K.; Munde, T.; Echeverri, F.; Quiñones, W.; Schneider, B. O-methylation of phenylphenalenone phytoalexins in Musa acuminata and Wachendorfia Thyrsiflora. Phytochemistry 2010, 71, 206-213. [CrossRef]

10. Nakazono, Y.; Watanabe, Y.; Hashinaga, F.; Tadera, K. Studies on Antimicrobial and Antioxidative Substance of Yuzu (Citrus junos hort. Ex Tanaka) Seed. J. Biol. Sci. 2006, 6, 135-139.

11. Tachai, S.; Nuntawong, N. Uncommon secondary metabolites from Etlingera pavieana rhizomes. Nat. Prod. Res. 2016, 30, 2215-2219. [CrossRef]

12. Kováčik, J.; Tomko, J.; Bačkor, M.; Repčák, M. Matricaria chamomilla is not a hyperaccumulator, but tolerant to cadmium stress. Plant Growth Regul. 2006, 50, 239-247. [CrossRef]

13. Hidalgo, W.; Kai, M.; Schneider, B. 4-Methoxycinnamic acid-An unusal phenylpropanoid involved in phenylphenalenone biosynthesis in Angiozanthos preissii. Phytochemistry 2015, 117, 476-481. [CrossRef] [PubMed]

14. Yun, B.R.; Yang, H.J.; Weon, J.B.; Lee, J.; Eom, M.R.; Ma, C.J. Neuroprotective Properties of Compounds Extracted from Dianthus superbus L. against Glutamate-induced Cell Death in HT22 Cells. Parmacognosy Mag. 2016, 12, 109-113.

15. Tang, K.S.C.; Konczak, I.; Zhao, J. Phenolic compounds of the Australian native herb Prostanthera rotundifolia and their biological activities. Food Chem. 2017, 233, 530-539. [CrossRef] [PubMed]

16. Kuroda, K.; Izumi, A.; Mazumder, B.B.; Ohtani, Y.; Sameshima, K. Characterization of kenaf (Hibiscus cannabinus) lignin by pyrolysis-gas chromatography-mass spectrometry in the presence of tetramethylammonium hydroxide. J. Anal. Appl. Pyrolysis 2002, 64, 453-463. [CrossRef]

17. Kuang, T.D.; Chen, H.Q.; Li, W.; Yang, J.L.; Zhou, L.M.; Cai, C.H.; Dong, W.H.; Mei, W.L.; Dai, H.F. A new sesquiterpene from Chinese agarwood induced by artificial holing. China J. Chin. Mater. Med. 2017, 42, 4618-4623. 
18. Jia, R.; Guo, Y.W.; Hou, H.X. Studies on the chemical constituents from leaves of Avicennia marina. Chin. J. Nat. Med. 2004, 2, $16-19$.

19. Abou-Zaid, M.M.; Nozzolillo, C.; Tonon, A.; Coppens, M.; Lombardo, D.A. High-Performance Liquid Chromatography Characterization and Identification of Antioxidant Polyphenols in Maple Syrup. Pharm. Biol. 2008, 46, 117-125. [CrossRef]

20. Zhang, P.; Yang, X.W. Studies on chemical constituents in roots and rhizomes od Notopterygium incisum. China J. Chin. Mater. Med. 2008, 33, 2918-2921.

21. Freitas, C.A.S.; Vieira, I.G.P.; Sousa, P.H.M.; Muniz, C.R.; Gonzaga, M.L.D.C.; Guedes, M.I.F. Carnauba wax $p$-methoxycinnamic diesters: Characterization, antioxidant activity and simulated gastrointestinal digestion followed by in vitro bioaccessibility. Food Chem. 2016, 196, 1293-1300. [CrossRef]

22. Rahman, A.A.; Moon, S.S. Antimicrobial Phenolic Derivatives from Dendranthema zawadskii var. latilobum Kitamura (Asteraceae). Arch. Pharmacal Res. 2007, 30, 1374-1379. [CrossRef]

23. Peng, W.; Han, T.; Liu, Q.; Qin, L. Chemical constituent from aerial part of Atractylodes macrocephala. China J. Chin. Mater. Med. 2011, 36, 578-581.

24. Ito, K.; Itoigawa, M.; Haruna, M.; Murata, H.; Furukawa, H. Dihydrochalcones from Balanophora tobiracola. Phytochemistry 1980, 19, 476-477. [CrossRef]

25. Zhang, Y.T.; Nie, H.; Zhou, D.X.; Chen, H.C.; Wu, L.D.; Tan, H.T.; Deng, S.P.; Li, J. Chemical constituents of Mallotus conspurcatus. Chin. Tradit. Herb. Drugs 2017, 48, 2172-2176.

26. Al-Taweel, A.M.; Perveen, S.; Fawzy, G.A.; Alqasoumi, S.I.; El-Tahir, K.E.H. New flavane gallates isolated from the leaves of Plicosepalus curviflorus and their hypoglycemic activity. Fitoterapia 2012, 83, 1610-1615. [CrossRef]

27. Nair, D.A.; James, T.J.; Sreelatha, S.L.; Kariyil, B.J.; Nair, S.N. Moringa oleifera (Lam.): A natural remedy for ageing? Nat. Prod. Res. 2020, 1-7. [CrossRef]

28. Chen, Y.T.; Liao, C.H.; Chen, I.S. Lignans, an amide and anti-platelet activities from Piper philippinum. Phytochemistry 2007, 68, 2101-2111. [CrossRef]

29. Kim, H.J.; Kang, M.A.; Kim, S.H.; Yim, S.H.; Lee, I.S. Bioactive Phenolic Constituents from the Culms of Phyllostachys bambusoides. Nat. Prod. Sci. 2011, 17, 267-272.

30. Duarte-Almeida, J.M.; Negri, G.; Salatino, A.; de Carvalho, J.E.; Lajolo, F.M. Antiproliferative and antioxidant activities of a tricin acylated glycoside from sugarcane (Saccharum officinarum) juice. Phytochemistry 2007, 68, 1165-1171. [CrossRef]

31. Cho, N.; Huh, J.; Yang, H.; Jeong, E.J.; Kim, Y.C.; Kim, J.; Sung, S.H. Chemical constituents of Polygala tenuifolia roots and their inhibitory activity on lipopolysaccharide-induced nitric oxide production in BV2 microglia. J. Enzym. Inhib. Med. Chem. 2012, 27, 1-4. [CrossRef]

32. Bylka, W. E- and Z-p-methoxycinnamic acid from Aquilegia vulgaris. Acta Pol. Pharm. 2004, 61, 307-308.

33. Wang, Z.W.; Xu, X.H.; Chen, X.T.; Yu, S.S.; Liu, H.D.; Hayashi, T.; Li, B. Chemical constituents from the aerial part of Sibiraea angustata. J. Chin. Med. Mater. 2014, 37, 57-60.

34. Messana, I.; Ferrari, F.; de Moraes e Souza, M.A.; Gács-Baitz, E. (-)-Salzol, an isopimarane diterpene, and a chalcone from Hyptis salzmanii. Phytochemistry 1990, 29, 329-332. [CrossRef]

35. Ito, C.; Kanbara, H.; Wu, T.S.; Furukawa, H. Murrayamine-C from Murraya euchrestifolia. Phytochemistry 1992, 31, $1083-1084$. [CrossRef]

36. Sun, W.B.; Yang, Z.; Liang, Y.; Li, L.; Hao, X.Y.; Zuo, G.Y.; Zhou, W. Chemical Constituents from n-Butanol Part in Toddalia asiatica Root Bark. Chin. Pharm. J. 2018, 53, 1052-1056.

37. Miyazawa, M.; Okuno, Y.; Nakamura, S.; Kameoka, H. Suppression of SOS-Inducing Activity of Chemical Mutagens by Cinnamic Acid Derivatives from Scrophulia ningpoensis in the Salmonella typhimurium TA1535/pSK1002 umu Test. J. Agric. Food Chem. 1998, 46, 904-910. [CrossRef]

38. Liu, Y.P.; Cai, X.H.; Li, W.Q.; Luo, X.D. Phenylpropanoid Esters of Rhamnose from Buddleja asiatica. Helv. Chim. Acta 2008, 91, 1299-1304. [CrossRef]

39. Zhu, L.J.; Hou, Y.L.; Shen, X.Y.; Pan, X.D.; Zhang, X.; Yao, X.S. Monoterpene pyridine alkaloids and phenolics from Scrophularia ningpoensis and their cardioprotective effect. Fitoterapia 2013, 88, 44-49. [CrossRef]

40. Kosuge, K.; Mitsunaga, K.; Koike, K.; Ohmoto, T. Studies on the Constituents of Ailanthus integrifolia. Chem. Pharm. Bull. 1994, 42, 1669-1671. [CrossRef]

41. Kuo, Y.H.; Chen, Z.S.; Lin, Y.L. Chemical Components of the Leaves of Duranta repens LINN. Chem. Pharm. Bull. 1996, 44, 429-436. [CrossRef]

42. Woo, W.S. p-Methoxycinnamate and Its Metabolite in Rabbit Serum. J. Pharm. Sci. 1968, 57, 27-30. [CrossRef] [PubMed]

43. Konishi, Y.; Kubo, K.; Shimizu, M. Structural Effects of Phenolic Acids on the Transepithelial Transport of Fluorescein in Caco-2 Cell Monolayers. Biosci. Biotechnol. Biochem. 2003, 67, 2014-2017. [CrossRef] [PubMed]

44. Wen, X.; Walle, T. Methylated Flavonoids have greatly improved intestinal absorption and metabolic stability. Am. Soc. Pharmacol. Exp. Ther. 2006, 34, 1786-1792. [CrossRef] [PubMed]

45. Huang, Y.; Law, J.C.F.; Zhao, Y.; Shi, H.; Zhang, Y.; Leung, K.S.Y. Fate of UV Ethylhexyl methoxycinnamate in rat model and human urine: Metabolism, exposure and demographic associations. Sci. Total Environ. 2019, 686, 729-736. [CrossRef] [PubMed] 
46. Fennell, T.R.; Mathews, J.M.; Snyder, R.W.; Hong, Y.; Watson, S.L.; Black, S.R.; Mclntyre, B.S.; Waidyanatha, S. Metabolism and disposition of 2-ethylhexyl- $p$-methoxycinnamate following oral gavage and dermal exposure in Harlan Sprague Dawley rats and B6C3F1/N mice and in hepatocytes in vitro. Xenobiotica 2018, 48, 1142-1156. [CrossRef] [PubMed]

47. Zanotti, I.; Dall'Astra, M.; Mena, P.; Mele, L.; Bruni, R.; Ray, S.; Del Rio, D. Atheroprotective effects of (poly)phenols: A focus on cell cholesterol metabolism. Food Funct. 2015, 6, 13-31. [CrossRef]

48. Grosso, G.; Stepaniak, U.; Micek, A.; Kozela, M.; Stefler, D.; Bobak, M.; Pajak, A. Dietary polyphenol intake and risk of hypertension in the Polish arm of the HAPIEE study. Eur. J. Nutr. 2018, 57, 1535-1544. [CrossRef]

49. Li, J.X.; Shi, Q.; Xiong, Q.B.; Prasain, J.K.; Tezuka, Y.; Hareyama, T.; Wang, Z.T.; Tanaka, K.; Namba, T.; Kadota, S. Tribulusamide $\mathrm{A}$ and $\mathrm{B}$, new hepatoprotective lignanamides from the fruits of Tribulus terrestris: Indications of cytoprotective activity in murine hepatocyte culture. Planta Med. 1998, 64, 628-631. [CrossRef]

50. Xiong, Q.; Fan, W.; Tezuka, Y.; Adnyana, I.K.; Stampoulis, P.; Hattori, M.; Namba, T.; Kadota, S. Hepatoprotective effect of Apocynum venetum and its active constituents. Planta Med. 2000, 66, 127-133. [CrossRef]

51. Lee, E.; Kim, S.; Kim, J.; Kim, Y. Hepatoprotective phenylpropanoids from Scrophularia buergeriana roots against $\mathrm{CCl}_{4}$-induced toxicity: Action mechanism and structure-activity relationship. Planta Med. 2002, 68, 407-411. [CrossRef] [PubMed]

52. Hikino, H.; Kiso, Y.; Wagner, H.; Fiebig, M. Antihepatotoxic actions of flavonolignans from Silybum marianum fruits. Planta Med. 1984, 50, 248-250. [CrossRef]

53. Fernández-Martinez, E.; Bobadilla, R.; Morales-Rios, M.; Muriel, P.; Perez-Alvarez, V. Trans-3-Phenyl-2-Propenoic Acid (Cinnamic Acid) Derivatives: Structure-Activity Relationship as Hepatoprotective Agents. Med. Chem. 2007, 3, 475-479. [CrossRef] [PubMed]

54. Qin, B.; Nagasaki, M.; Ren, M.; Bajotto, G.; Oshida, Y.; Sato, Y. Cinnamon extract (traditional herb) potentiates in vivo insulinregulated glucose utilization via enhancing insulin signaling in rats. Diabetes Res. Clin. Pract. 2003, 62, 139-148. [CrossRef]

55. Khan, A.; Safdar, M.; Ali Khan, M.M.; Khattak, K.N.; Anderson, R.A. Cinnamon improves glucose and lipids of people with type 2 diabetes. Diabetes Care 2003, 26, 3215-3218. [CrossRef] [PubMed]

56. Adisakwattana, S.; Sookkongwaree, K.; Roengsumran, S.; Petsom, A.; Ngamrojnavanich, N.; Chavasiri, W.; Yibchok-anun, S. Structure-activity relationships of trans-cinnamic acid derivatives on a-glucosidase inhibition. Bioorganic Med. Chem. Lett. 2004, 14, 2893-2896. [CrossRef] [PubMed]

57. Adisakwattana, S.; Roengsamran, S.; Hsu, W.H.; Yibchok-anun, S. Mechanisms of antihyperglycemic effect of $p$-methoxycinnamic acid in normal and streptozotocin-induced diabetic rats. Life Sci. 2005, 78, 406-412. [CrossRef] [PubMed]

58. Yibchok-anun, S.; Adisakwattana, S.; Moonsan, P.; Hsu, W.H. Insulin-Secretagogue Activity of $p$-Methoxycinnamic Acid in Rats Perfused Rat Pancreas and Pancreatic $\beta$-Cell Line. Basic Clin. Pharmacol. Toxicol. 2008, 102, 476-482. [CrossRef] [PubMed]

59. Adisakwattana, S.; Moonsan, P.; Yibchok-Anun, S. Insulin-Releasing Properties of a Series of Cinnamic Acid Derivatives in Vitro and in Vivo. J. Agric. Food Chem. 2008, 56, 7838-7844. [CrossRef]

60. Adisakwattana, S.; Hsu, W.H.; Yibchok-Anun, S. Mechanism of $p$-Methoxycinnamic Acid-induced Increase in Insulin Secretion. Horm. Metab. Res. 2011, 43, 766-773. [CrossRef] [PubMed]

61. Adisakwattana, S.; Sompong, W.; Meeprom, A.; Ngamukote, S.; Yibchok-anun, S. Cinnami Acid and Its Derivatives Inhibit Fructose-Mediated Protein Glycation. Int. J. Mol. Sci. 2012, 13, 1778-1789. [CrossRef]

62. Gunasekaran, S.; Venkatachalam, K.; Namasivayam, N. p-Methoxycinnamic acid, an active phenylpropanoid induces mitochondrial mediated apoptosis in HCT-116 human colon adenocarcinoma cell line. Environ. Toxicol. Pharmacol. 2015, 40, 966-974. [CrossRef]

63. Gunasekaran, S.; Venkatachalam, K.; Namasivayam, N. Anti-inflammatory and anticancer effects of $p$-methoxycinnamic acid, an active phenylpropanoid, against 1,2-dimethylhydrazine-induced rat colon carcinogenesis. Mol. Cell. Biochem. 2019, 451, 117-129. [CrossRef] [PubMed]

64. Kim, S.R.; Kang, S.Y.; Lee, K.Y.; Kim, S.H.; Markelonis, G.J.; Oh, T.H.; Kim, Y.C. Anti-amnestic activity of E-p-methoxycinnamic acid from Scrophularia buergeriana. Cogn. Brain Res. 2003, 17, 454-461. [CrossRef]

65. Gunasekaran, S.; Venkatachalam, K.; Jeyavel, K.; Namasivayam, N. Protective effect of $p$-methoxycinnamic acid, an active phenolic acid against 1,2-dimethylhydrazine-induced colon carcinogenesis: Modulating biotransforming bacterial enzymes and xenobiotic metabolizing enzymes and xenobiotic metabolizing enzymes. Mol. Cell Biochem. 2014, 394, 187-198. [CrossRef] [PubMed]

66. Kim, S.R.; Kim, Y.C. Neuroprotective phenylpropanoid esters of rhamnose isolated from roots of Scrophularia buergeriana. Phytochemistry 2000, 54, 503-509. [CrossRef]

67. Kim, S.R.; Sung, S.H.; Jang, Y.P.; Markelonis, G.J.; Oh, T.H.; Kim, Y.C. E-p-Methoxycinnamic acid protects cultured neuronal cells against neurotoxicity induced by glutamate. Br. J. Pharmacol. 2002, 135, 1281-1291. [CrossRef]

68. Rijal, S.; Changdar, N.; Kinra, M.; Kumar, A.; Nampoothiri, M.; Arora, D.; Shenoy, R.R.; Ranganath Pai, K.S.; Joseph, A.; Mudgal, J. Neuromodulatory potential of phenylpropanoids; para-methoxycinnamic acid and ethyl-p-methoxycinnamate on aluminum-induced memory deficit in rats. Toxicol. Mech. Methods 2019, 29, 334-343. [CrossRef]

69. Narasimhan, B.; Belsare, D.; Pharande, D.; Mourya, V.; Dhake, A. Esters, amides and substituted derivatives of cinnamic acid: Synthesis, antimicrobial activity and QSAR investigations. Eur. J. Med. Chem. 2004, 39, 827-834. [CrossRef]

70. Guzman, J.D. Natural cinnamic acids, synthetic derivatives and hybrids with antimicrobial activit. Molecules 2014, 19, 19292-19349. [CrossRef] 
71. Malheiro, J.F.; Maillard, J.Y.; Borges, F.; Simões, M. Evaluation of cinnamaldehyde and cinnamic acid derivatives in microbial growth control. Int. Biodeterior. Biodegrad. 2019, 141, 71-78. [CrossRef]

72. Cheng, W.J.; Zhou, J.W.; Zhang, P.P.; Luo, H.Z.; Tang, S.; Li, J.J.; Deng, S.M.; Jia, A.Q. Quorum sensing inhibition and tobramycin acceleration in Chromobacterium violaceum by two natural cinnamic acid derivatives. Appl. Microbiol. Biotechnol. 2020, 104, 5025-5037. [CrossRef] [PubMed]

73. Witekamp, P.; Vosmann, K.; Weber, N. Highly Efficient Preparation of Lipophilic Hydroxycinnamates by Solvent-free LipaseCatalyzed Transesterification. J. Agric. Food Chem. 2006, 54, 7062-7068. [CrossRef] [PubMed]

74. Lee, G.-S.; Widjaja, A.; Ju, Y.-H. Enzymatic synthesis of cinnamic acid derivatives. Biotechnol. Lett. 2006, 28, 581-585. [CrossRef] [PubMed]

75. Kumar, V.; Jahan, F.; Kameswaran, K.; Mahajan, R.V.; Saxena, R.K. Eco-friendly methodology for efficient synthesis and scale-up of 2-ethylhexyl-p-methoxycinnamate using Rhizopus oryzae lipase and its biological evaluation. J. Ind. Microbiol. Biotechnol. 2014, 41, 907-912. [CrossRef] [PubMed]

76. Menezes, J.C.J.M.D.S.; Kamat, S.P.; Cavaleiro, J.A.S.; Gaspar, A.; Garrido, J.; Borges, F. Synthesis and antioxidant activity of long chain alkyl hydroxycinnamates. Eur. J. Med. Chem. 2011, 46, 773-777. [CrossRef] [PubMed]

77. Czarnecka, M.; Świtalska, M.; Wietrzyk, J.; Maciejewska, G.; Gliszczyńska, A. Synthesis, Characterization, and In Vitro Cancer Cell Growth Inhibition Evaluation of Novel Phosphatidylcholines with Anisic and Veratric Acids. Molecules 2018, $23,2022$. [CrossRef]

78. Czarnecka, M.; Świtalska, M.; Wietrzyk, J.; Maciejewska, G.; Gliszczyńska, A. Synthesis and biological evaluation of phosphatidylcholines with cinnamic and 3-methoxycinnamic acids with potent antiproliferative activity. RSC Adv. 2018, 8, 35744-35752. [CrossRef]

79. Yang, H.; Mu, Y.; Chen, H.; Xiu, Z.; Yang, T. Enzymatic synthesis of feruloylated lysophospholipid in a selected organic solvent medium. Food Chem. 2013, 141, 3317-3322. [CrossRef]

80. Okulus, M.; Gliszczyńska, A. Enzymatic synthesis of $O$-methylated phenophospholipids by lipase-catalyzed acidolysis of egg-yolk phosphatidylcholine with anisic and veratric acids. Catalysts 2020, 10, 538. [CrossRef]

81. Rychlicka, M.; Maciejewska, G.; Niezgoda, N.; Gliszczyńska, A. Production of feruloylated lysophospholipids via a one-step enzymatic interesterification. Food Chem. 2020, 323, 126802. [CrossRef]

82. Rychlicka, M.; Gliszczyńska, A. Interesterification of Egg-Yolk Phosphatidylcholine with $p$-Methoxycinnamic Acid Catalyzed by Immobilized Lipase B from Candida Antarctica. Catalysts 2020, 10, 1181. [CrossRef]

83. Rychlicka, M.; Rot, A.; Gliszczyńska, A. Biological Properties, Health Benefits and Enzymatic Modifications of Dietary Methoxylated Derivatives of Cinnamic Acid. Foods 2021, 10, 1417. [CrossRef]

84. Rychlicka, M.; Niezgoda, N.; Gliszczyńska, A. Development and Optimization of Lipase-Catalyzed Synthesis of Phospholipids Containing 3,4-Dimethoxycinnamic Acid by Response Surface Methodology. Catalysts 2020, 10, 588. [CrossRef] 